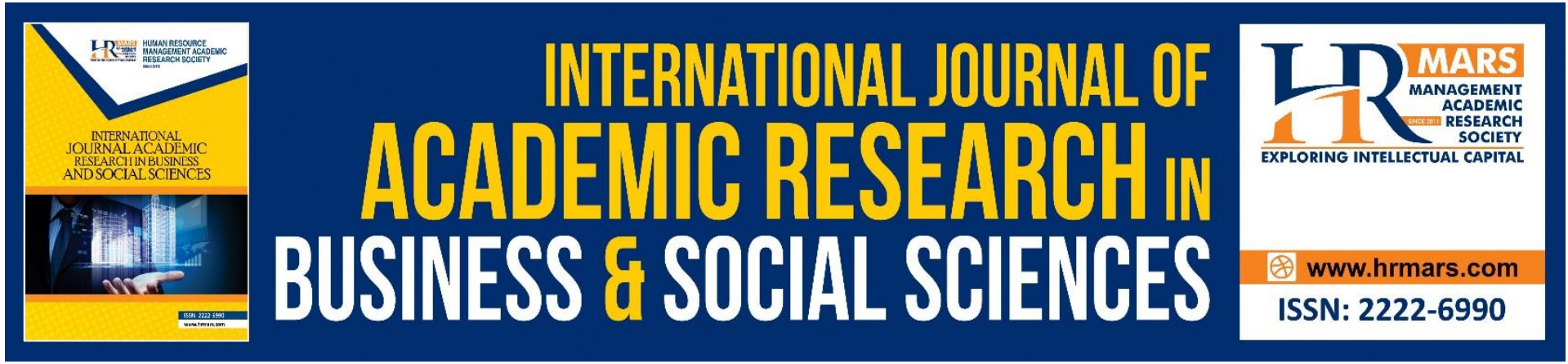

\title{
Identifying Language Learning Strategy Employed by Malaysian Upper Primary ESL Learners
}

Nur Maechea Avelino, Winson Eng Wei Siang, Dhaayaaliny A/P Pasupathy, Wan Mohd Suhairi Abdullah Saimi, Shazwina Shamien Abdul Basit, Nurrul Aqilah Ismail, Harwati Hashim

To Link this Article: http://dx.doi.org/10.6007/IJARBSS/v11-i6/10061 DOI:10.6007/IJARBSS/v11-i6/10061

Received: 19 April 2021, Revised: 22 May 2021, Accepted: 04 June 2021

Published Online: 28 June 2021

In-Text Citation: (Avelino et al., 2021)

To Cite this Article: Avelino, N. M., Siang, W. E. W., Pasupathy, D. A., Saimi, W. M. S. A., Basit, S. S. A., Ismail, N. A. \& Hashim, H. (2021). Identifying Language Learning Strategy Employed by Malaysian Upper Primary ESL Learners. International Journal of Academic Research in Business and Social Sciences, 11(6), 1651-1664.

Copyright: (c) 2021 The Author(s)

Published by Human Resource Management Academic Research Society (www.hrmars.com)

This article is published under the Creative Commons Attribution (CC BY 4.0) license. Anyone may reproduce, distribute, translate and create derivative works of this article (for both commercial and non-commercial purposes), subject to full attribution to the original publication and authors. The full terms of this license may be seen at: http://creativecommons.org/licences/by/4.0/legalcode

Vol. 11, No. 6, 2021, Pg. 1651 - 1664

http://hrmars.com/index.php/pages/detail/IJARBSS

JOURNAL HOMEPAGE

Full Terms \& Conditions of access and use can be found at http://hrmars.com/index.php/pages/detail/publication-ethics 


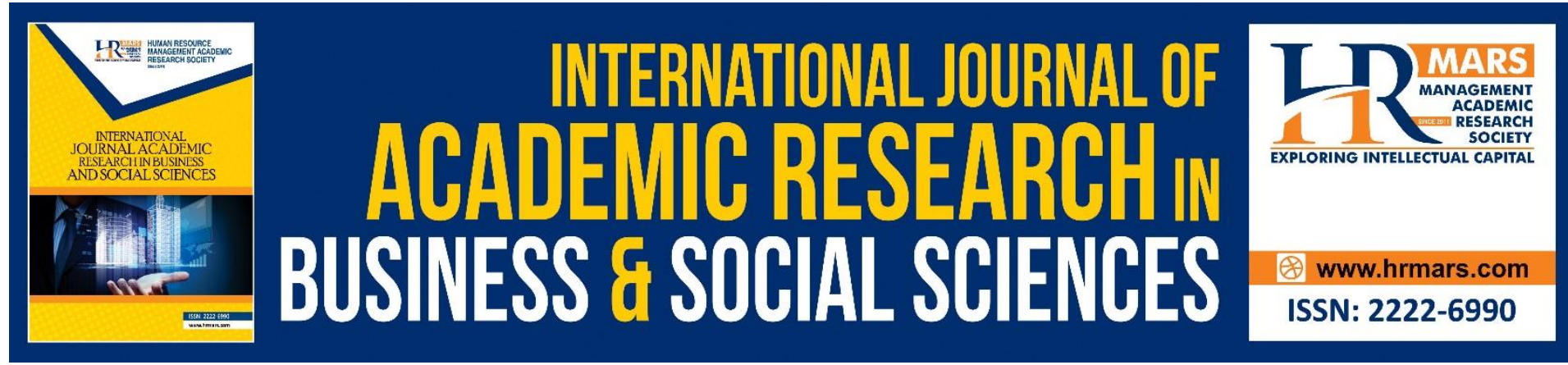

\title{
Identifying Language Learning Strategy Employed by Malaysian Upper Primary ESL Learners
}

\author{
Nur Maechea Avelino, Winson Eng Wei Siang \\ SJKC Ladang Grisek, Pasir Gudang, 81700, Johor. \\ Email:maechea04@gmail.com,winsonews@gmail.com
}

Dhaayaaliny A/P Pasupathy

SJKC Tanah Merah Site C Pos Bukit Pelandok 71960, Seremban, Negeri Sembilan.

Email: dhaayaaliny@gmail.com

\author{
Wan Mohd Suhairi Abdullah Saimi \\ SK Lembah Bidong, 21030 Setiu, Terengganu. \\ Email: wanmohdsuhairi@gmail.com
}

\section{Shazwina Shamien Abdul Basit}

SK Taman Bukit Indah, 79100, Iskandar Puteri, Johor.

Email: shamien@sktbijohor.edu.my

Nurrul Aqilah Ismail

SJKC Khai Chee, Segambut, 51200 Kuala Lumpur.

Email: nurruls1993@gmail.com

\section{Harwati Hashim}

Faculty of Education, Universiti Kebangsaan Malaysia, Bangi 43000 Selangor Malaysia

Email: harwati@ukm.edu.my

\begin{abstract}
Language Learning Strategies (LLS) are used to facilitate independent-learning and make it adaptable to new language tasks. However, most of LLS are focused more on adults compare to children so there is limited research on LLS for children. Therefore, this paper provides an overview how researchers used CHILLS questionnaire to investigate LLS that commonly used among Malaysian Upper Primary English as a Second Language (ESL) Learners in the second language acquisition. The data and findings are collected from 105 participants from different primary schools across Malaysia. This paper is hoped to render a better understanding on the process of effective language learning using the discussed LLS among Malaysian Upper Primary ESL Learners. The data have indicated that learners prefer to use LLS strategies in Part A of CHILLS questionnaire compared to other parts. The researchers also aim to conduct
\end{abstract}


future study in lower primary or pre-school learners. This research hopes to enlighten the stakeholders concerned to be conscious of different types of LLS when designing the syllabus and curriculum.

Keywords: Language Learning Strategies, English as a Second Language (ESL), Upper Primary Learners, Children's Inventory for Language Learning (CHILLS), Second Language Acquisition

\section{Introduction}

In a language classroom, there are 4 predominant language skills a learner needs to master, namely listening, speaking, reading and writing. In effect, learners of English as a second language (ESL) can and will communicate with the community using both oral and written language forms fluently, proficiently and effectively (Khusnul, 2020). Language has been highly utilised in the cascading of information and knowledge around the world. Bhasin (2020) states that language is a formal system that is used as an important means of communicating the ideas and thoughts from one to another individual to encourage intellectual development.

The significance of learning a language especially a second language (L2) has increased incredibly throughout the years due to its essential role in education where the emphasis has been placed on the learners. According to Lessard (1997), a gradual but significant shift has taken place within the field of education over the last few decades, resulting in greater stress on learners and learning, hence less emphasis on teachers and teaching. Due to the emphasis gravitated on the learners and learning, the existence of various language learning strategies (LLS) has been an important aspect in language acquisition.

Chamot (1987) defines learning strategies as processes, techniques, approaches and actions that learners take to facilitate the learning and recall of both linguistics and content areas of information. This definition is further elaborated by O'Malley and Chamot (1990) who mention that LLS involve techniques and devices used by L2 learners to remember and organise samples of L2 by comprehending, learning or retaining new information through analysis and monitoring. The selection of the right LLS is very crucial in ensuring learners to have the optimum and correct ways to acquire a language especially L2 effectively.

O' Malley and Chamot (1990) also imply that effective language learners are aware of the strategies they use and why they use them. It is vital for language learners to discover and utilise the appropriate LLS as failing to do so will result in the inefficiency of language learning which will deter the learners to develop their intellect. According to Ismail and Jabar (2010), some strategies may not be responsive as learners are unable to develop the right approach to learning since they are oblivious of the suitability of the strategy used towards their language learning capability. According to Nguyen and Terry (2017), there is also a requirement to use learning strategies and chances to the learners to explore what is best for them to use. Thus, selecting the right LLS is ultimately important to the learners as they play an important role in learning the intended language efficaciously.

\section{Research Aim}

The role of LLS has widely been reported, however, the role of LLS in ensuring an effective language learning takes place among Malaysian upper primary English as a Second Language (ESL) learners has not been dwelt into thoroughly. Therefore, the aim of this paper is to gain an in-depth understanding on the vital role of LLS in learning a supposed language effectively among Upper Primary ESL learners in Malaysia. 


\section{Research Objectives}

The objectives of this research are to:

1. Investigate the overall use of LLS among learners in Upper Primary ESL classes in Malaysia.

2. Identify the most frequently used group of LLS by these young learners.

3. Identify the most and the least strategies used in each category of LLS employed by these young learners.

\section{Literature Review}

\section{$21^{\text {st }}$ Century Primary ESL Classroom in Malaysia}

The technological era of today posits numerous remarkable impacts on education around the globe. According to Brown (2000) as cited in Rukaia (2017), ESL learning suggests some degree in the procurement of a second culture and identity. In the language teaching and learning process, ESL teachers are the key figures who play multiple roles in triggering learners' interest and effort, hence making their impact essential to learners' progress. Looking at the native context, Malaysia has experienced its transition from obsolete teaching strategies to sophisticated teaching methodologies. Instead of sticking within the four walls of a classroom, the integration of Information Communication and Technologies (ICT) has widely been discussed (Nadzrah, 2007). According to NoorAileen et al. (2015), primary ESL classrooms serve as a discussion platform for teachers and learners to generate ideas and better understanding. Li (2019) also proposes the incorporation of new digital channels such as the Internet and social networking has not only altered the way of communication, but also induced learners to process information from a broader spectrum.

NoorAileen et al. (2015) highlight the importance of collaborative learning in education when $21^{\text {st }}$ century elements are involved. They claim that meaningful interaction and creative ideas can be blossomed upon guidance by the teachers. It is in parallel with Akhyar and Fatimah (2018) who agree that the practice of teaching and learning is closely interwoven. On the other hand, Nadzrah (2007) as reviewed in Li (2019) discovers that ESL classrooms are often found active when learners are aware of the cultural and social relevance. In effect, the manipulation of resources may influence and contribute to effective learning. According to Khalid (2017), fulfilling optimal success in the teaching of ESL requires teachers to illustrate dynamic and fundamental features that comprise several underpinnings and interacting constructs. This is why ESL teachers in the primary schools must invest meticulous thought into the design of instructional strategies in order to ensure its successful implementation. As a result, ESL teachers will leave a visionary and impressive impact on the learners' ESL learning endeavours.

\section{Classification of Language Learning Strategy}

According to Oxford (1990) and Cohen (1998) as cited in Safranj and Gojkov-Rajic (2018), LLS refer to conscious operations a learner applies in foreign language learning to improve the acquisition, memory and application of stored information. In other words, ESL learners employ various strategies to facilitate independent learning and make it adaptable to new language tasks. Similarly, Gürsoy (2013) explains that learning needs between young learners and adults cannot be compared due to limited cognitive abilities, world, conceptual and linguistic knowledge. In brief, LLS possess a number of characteristics (Safranj \& Gojkov-Rajic, 2018) such as (a) conscious effort, (b) self-regulated, (c) affect the success of foreign language 
adoption and (d) learners are highly susceptible to change. When learners become skilled in the exercise of those strategies, hence autonomous is derived.

As a matter of fact, there is a library of research pertaining to various language learning taxonomies that are worth mentioning. Bialystok (1978) as reviewed in Gürsoy (2013) defines learning strategies as alternative methods for gaining proficiency in a second language by using accessible information. The researcher classifies learning strategies as formal practicing, functional practicing, inferencing and monitoring. Rubin (1981) as referred by Lawrence, Nathan and Tony (2019) identifies two categories for language learning which are implicit and explicit learning strategies. On another research, O'Malley and Chamot (1990) as cited in Namaziandost, Imani and Ziafar (2020) categorise language learning as metacognitive, cognitive and social strategies. Of all the LLS groups, Oxford's classification (1990) as cited in Alhaysony (2017) is by far the most commonly used scheme. The types of LLS proposed by Oxford are showcased in Table 1. Above and beyond, it is expected that these LLS could entail significant attributes to the ESL learners through extensive review of literature.

Table 1. Language Learning Strategies (Oxford, 1990)

\begin{tabular}{|c|c|c|}
\hline \multicolumn{3}{|c|}{ Language Learning Strategies } \\
\hline Direct strategies & Memory strategies & $\begin{array}{l}\text { - } \quad \text { Creating mental connections } \\
\text { - Applying images and sounds } \\
\text { - Reviewing } \\
\text { - Employing actions }\end{array}$ \\
\hline \multirow{5}{*}{$\begin{array}{l}\text { Indirect } \\
\text { strategies }\end{array}$} & Cognitive strategies & $\begin{array}{l}\text { - } \text { Rehearsing } \\
\text { - } \text { Receiving and transmitting messages } \\
\text { - } \quad \text { Analysing and reasoning } \\
\text { - } \quad \text { Creating structure for input and output }\end{array}$ \\
\hline & $\begin{array}{l}\text { Compensation } \\
\text { strategies }\end{array}$ & $\begin{array}{l}\text { - Guessing intelligently } \\
\text { - Overcome weaknesses in oral and } \\
\text { written forms }\end{array}$ \\
\hline & $\begin{array}{l}\text { Metacognitive } \\
\text { strategies }\end{array}$ & $\begin{array}{l}\text { - } \quad \text { Learning centre } \\
\text { - } \quad \text { Learning plan and arrangement } \\
\text { - } \quad \text { Learning evaluation }\end{array}$ \\
\hline & Affective strategies & $\begin{array}{l}\text { - } \quad \text { Lowering anxiety } \\
\text { - } \quad \text { Encouraging ownself } \\
\text { - } \quad \text { Taking emotional temperature }\end{array}$ \\
\hline & Social strategies & $\begin{array}{ll}\text { - } & \text { Inquiries } \\
\text { - } & \text { Cooperation } \\
\text { - } & \text { Empathy } \\
\end{array}$ \\
\hline
\end{tabular}

\section{Factors Affecting Language Learning Strategy}

There are several variables contributing to LLS. According to Gürsoy and Eken (2017), individual variables such as age, gender, attitude, learning styles, motivation and proficiency are some factors that could bring numerous insightful impacts to LLS. Let's take an example from the gender perspective. Some past studies have highlighted those female learners are more frequent users of LLS (Gürsoy \& Eken, 2017). Additionally, Zeynali (2012) has proposed a number of factors influencing gender differences in second language strategies such as 
personality, cognitive style or attitude. In other words, female superiority is attributed to their greater social orientation and stronger communication skills.

The earlier attempts on identifying LLS adopted by good language learners have led the researchers to examine the relationship between LLS and success. It has been concluded that high achievers apply a wide range of LLS as opposed to those who seldom or hardly use LLS being in the category of underachieving counterparts (Hong-Nam \& Leavell, 2007). Nevertheless, the question that remains with us is whether the LLS used by adults differ from young learners. Purdie and Oliver (as cited in Gürsoy \& Eken, 2017) proclaim that from the aspect of psychologically and socially, language learning strategies used by adults are different from young learners. In lieu of that, there have even been calls to disentangle LLS from self-regulation and view strategic learning on a continuum to acknowledge that otherregulated LLS use may indeed be prevalent, especially in formal education settings for young learners.

\section{Methodology}

This undertaken study aims to investigate an overall understanding for the research of LLS employed by Upper Primary ESL learners. This study is significant in the research field through the investigation of preferred Upper Primary level learners' choices of LLS without any specification of language skill or strategy types. Thus, the researchers have employed a survey design in answering the research questions as follows:

1. What is the overall use of LLS among learners in Upper Primary ESL classes in Malaysia?

2. What is the most frequently used group of LLS by these young learners?

3. What are the most and the least strategies used in each category of LLS employed by these young learners?

\section{Participants and Instrument}

Kumar (2011) defined research design as a plan, structure and strategy that researchers used to answer research questions or problem. This research is a quantitative research as it replicated and adopted the questionnaire in order to verify type of learning strategies that pupils prefer. Researchers chose quantitative design as they want to identify type of Language Learning Strategy (LLS) that their pupils preferred in order to plan more cohesive and meaningful lesson plan for their pupils. There are three main interrelated steps in the process sampling and data collection that proposed by Creswell (2012).

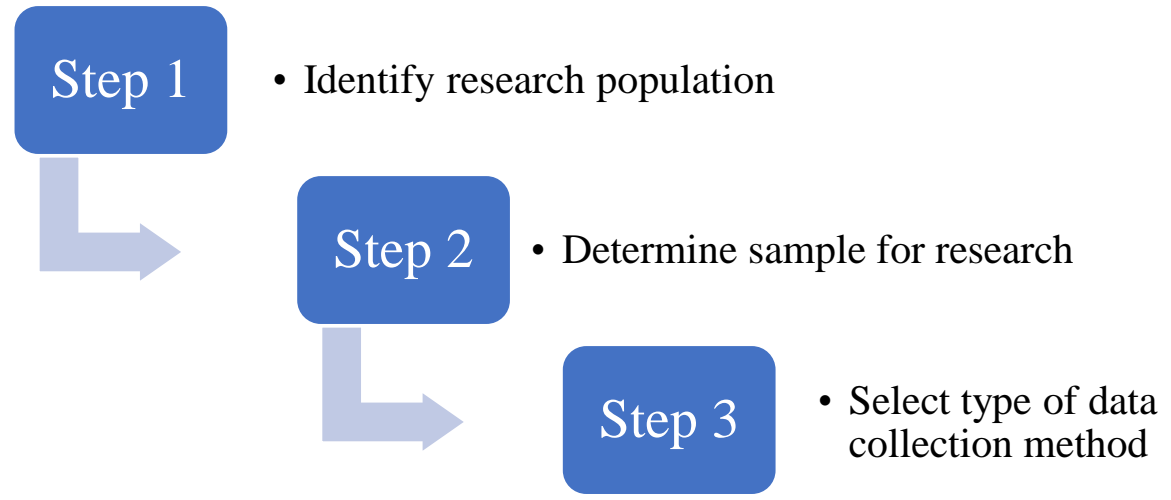

Figure 1. Steps in the process sampling and data collection (Creswell, 2012) 
The first step taken by the researcher is to identify the research population as they consider two types of population - wider and target population. Researchers want to determine the types of population as this research is an educational research that needs to be explicitly addressed. Therefore, the wider population for this research is learners in primary schools but the target population is learners in Upper Primary schools in targeted states such as Johor, Negeri Sembilan, Kuala Lumpur and Terengganu.

The second step is determining the research sample within the target population as researchers need to get their permission prior to conducting the study. Welkowitz, Cohen and Ewen (2009) as cited in Boset et al. (2017) highlight that the indispensable part for hypothesis testing is the appropriate sample size to ensure that researchers can get accurate measurement. As mentioned earlier, the sample for this research is learners of Upper Primary schools from four states - Johor, Negeri Sembilan, Kuala Lumpur and Terengganu in order to represent the general preference of learners in Malaysian primary schools. In relation to that, there are 105 Upper Primary learners from different types of primary schools across Malaysia chosen as the participants for this research. The participants' age ranges from 10 years old to 12 years old.

The last step is identifying the type of data collection method, determining the instrument for data collection and collecting the data. Data collection method used in this research is survey where verified questionnaire is used to investigate pupils' preferences in LLS. The questionnaire used for this research has been tested for validity and reliability by Gürsoy (2013) where the researcher has distributed a total of 109 questionnaire items to 10 experts from English Language Teaching Educational Science Departments to test face validity of the instruments and three experts from English Language Teaching (ELT) Departments to test the content validity. Therefore, having administered few pilot tests and a study conducted, a valid and reliable inventory for children's LLS named Children's Inventory for Language Learning (CHILLS) is developed (Gürsoy, 2013). CHILLS is the instrument used to answer the research questions of this research.

\section{Data Collection and Analysis}

The inventory has been administered to the participants by the researchers, who are also their English language teachers. Instructions in the first language L1 (Malay) is provided before administering the questionnaire in two modes, online and manual copies. The data have been analysed through SPSS 26 . Respectively, the overall use of LLS use among learners in Upper Primary ESL classes in Malaysia, the most frequently used group of LLS by these young learners as well as the the most and the least used LLS employed by these young learners have been identified descriptively

\section{Results}

The first question of this research investigates the overall Language Learning Strategies (LLS) used by learners in ESL upper primary classes in Malaysia. The instrument is build based on a 3-point Likert scale with the minimum score of 30 and the maximum score of 90 . The questionnaire is divided into 4 parts; Part A, Part B, Part C and Part D.

Part $A$ refers to cognitive, metacognitive strategies and two social strategies that describe the general study habits of young learners. One of the strategies in Part A is leaners can use new vocabulary they recently learnt to practice their pronunciation and they also can inform their parents whenever their need help to learn the target language. Similarly, Part B entails cognitive, metacognitive, social and compensation strategies that describe strategies 
mostly used to improve language learning. Some of the questionnaire items in Part B evolves around cognitive strategies where learners might use different words that might have a similar meaning instead of the words that they are unfamiliar with or they can use English language in fun ways such as making a joke in English. Part $C$, on the other hand, encompasses compensation, memory and cognitive strategies that describe how strategies are used for facilitation of the reception and production of the target language. For instance, learners make an association between the pronunciation of two words from foreign language and their mother tongue to recall new vocabulary in their mind as reception of the target language. Meanwhile in order to produce the target language, learners can draw the picture of unknown vocabulary when they are speaking or writing. Ultimately, Part D describes strategies that help learners to consolidate their learning of the target language. One of the strategies in Part $D$ is learners can rehearse new information by listening and reading a passage twice in the intended language. It also functions as a self-reflection process where learners commodify their language skills to help regulate their language learning in the second language acquisition. The description of categories for each part can be summarised in Table 2 .

Table 2. Description of LLLS Categories

\begin{tabular}{ll}
\hline Categories & Description \\
\hline Part A & $\begin{array}{l}\text { Cognitive, metacognitive strategies and two social strategies that } \\
\text { describe the general study habits of young learners. } \\
\text { Part B }\end{array}$ \\
Cognitive, metacognitive, social and compensation strategies that \\
describe strategies mostly used to improve language learning. \\
Compensation, memory and cognitive strategies that describe how \\
strategies are used to facilitate the reception and production of the \\
target language. \\
Part D
\end{tabular}

The first research question of this research has been answered based on the results in Table 3 that indicate the overall use of LLS among learners in Upper Primary ESL classes in Malaysia where we can see that Part $A$ that describe the general study habits of young learners posits a percentage of $25.26 \%$. Part B with each is about strategies mostly used to improve language learning carries a percentage of $25.35 \%$. The category that describes how strategies are used to facilitate the reception and production of the target language is Part C with a percentage of $24.08 \%$. Lastly, Part D that describe how learners consolidate their learning of the target language has percentage of $25.31 \%$.

The second research question of this research can be found in Table 3 that indicate the most frequently used group of LLS by these young learners. The result displays the highest category of LLS used among young learners is Part B with the percentage of $25.35 \%$. This shows that young learners prefer to use cognitive, metacognitive, social and compensation strategies to improve their language learning. On the other hand, the lowest category of LLS is Part C with the percentage of $24.08 \%$ which indicated that young learners are in favour of compensation, memory and cognitive strategies used to facilitate the reception and production of the target language. 
Table 3. LLS use by learners in ESL's upper primary classes in Malaysia

\begin{tabular}{|c|c|c|c|c|c|c|}
\hline \multicolumn{7}{|l|}{ Statistics } \\
\hline & & PARTA & PARTB & PARTC & PARTD & Total \\
\hline \multirow{2}{*}{$\mathrm{N}$} & Valid & 105 & 105 & 105 & 105 & 105 \\
\hline & Missing & 0 & 0 & 0 & 0 & 0 \\
\hline Mean & & 2.2505 & 2.2583 & 2.1456 & 2.2552 & 8.9096 \\
\hline Percentage & & $25.26 \%$ & $25.35 \%$ & $24.08 \%$ & $25.31 \%$ & $100 \%$ \\
\hline
\end{tabular}

The third research question of this research is to identify most used and the least used learning strategies employed by these learners. Based on Table 4, learners more prefer to tell their parents that they need help when they faced difficulties to learn something with the highest mean, 2.44 in Part A. Meanwhile, in Part B based on Table 5, learners preferred to think of words that might have similar meaning instead of using words that they didn't know when they are speak with the highest mean of 2.43. Based on Table 6, the most used strategy in Part $\mathrm{C}$ is when learners get benefits when they try to facilitate their writing and reading comprehension by using words that have same meaning but in different languages with the highest mean of 2.29 in Part C meanwhile in Part D, the most strategy used was identifying the words and structures from their book and notebooks before they write something with the highest mean, 2.29 as shown in Table 7.

On the other hand, we can see that based on Table 4, learners least prefer to check their book, notebooks or other materials before they speak English with the lowest mean of 2.03 in Part A. Meanwhile, in Part B based on Table 5, we can see that learners use the words they learnt recently when they are speaking with tourist or native speakers is the least used strategy with the lowest mean of 2.1 in Part B. Based on Table 6, the least used strategy in Part $C$ is when learners draw unknown word when they are writing or speaking with the lowest mean of 1.85 in Part C meanwhile in Part D, learners used the least strategy to think the location of the word in a page when they try to recall words with the lowest mean of 2.22 as shown in Table 7. 
Table 4. Mean for Part A

\begin{tabular}{|c|c|c|c|c|}
\hline \multicolumn{5}{|l|}{ One-Sample Statistics } \\
\hline & $\mathrm{N}$ & Mean & $\begin{array}{l}\text { Std. } \\
\text { Deviation }\end{array}$ & $\begin{array}{l}\text { Std. } \\
\text { Error } \\
\text { Mean }\end{array}$ \\
\hline $\begin{array}{l}\text { I try to speak in English with my teacher, friends } \\
\text { and parents }\end{array}$ & 105 & 2.39 & .612 & .060 \\
\hline $\begin{array}{l}\text { In an activity I work with my friend, I share my } \\
\text { notes or ask them the points I don't understand }\end{array}$ & 105 & 2.37 & .683 & .067 \\
\hline $\begin{array}{l}\text { I ask my teacher, friend, or someone who is } \\
\text { knowledgeable to correct my errors after writing } \\
\text { or saying something in English }\end{array}$ & 105 & 2.36 & .786 & .077 \\
\hline $\begin{array}{l}\text { I use a new vocabulary in sentence to pronounce it } \\
\text { correctly }\end{array}$ & 105 & 2.19 & .708 & .069 \\
\hline $\begin{array}{l}\text { Before I say something in English I check my book, } \\
\text { notebook and others material to see what we } \\
\text { learned about the topic }\end{array}$ & 105 & 2.03 & .837 & .082 \\
\hline I test myself to improve my English & 105 & 2.21 & .781 & .076 \\
\hline $\begin{array}{l}\text { I revise the lesson, the notes I take at school, my } \\
\text { old books and notebooks, unknown or newly } \\
\text { learnt vocabulary by reading or writing }\end{array}$ & 105 & 2.04 & .759 & .074 \\
\hline $\begin{array}{l}\text { I practice with my parents or someone else before } \\
\text { speaking activities }\end{array}$ & 105 & 2.15 & .852 & .083 \\
\hline I study my errors after speaking activities & 105 & 2.32 & .740 & .072 \\
\hline $\begin{array}{l}\text { When I think that I cannot learn I tell my parents I } \\
\text { need help. Example: I go to tuition class }\end{array}$ & 105 & 2.44 & .784 & .076 \\
\hline Total & 105 & 22.5 & 3.8931 & \\
\hline
\end{tabular}


Table 5. Mean for Part B

\begin{tabular}{|c|c|c|c|c|}
\hline \multicolumn{5}{|l|}{ One-Sample Statistics } \\
\hline & $\mathrm{N}$ & Mean & $\begin{array}{l}\text { Std. } \\
\text { Deviation }\end{array}$ & $\begin{array}{l}\text { Std. } \\
\text { Error } \\
\text { Mean }\end{array}$ \\
\hline $\begin{array}{l}\text { I read the books I read before to improve my } \\
\text { English }\end{array}$ & 105 & 2.36 & .695 & .068 \\
\hline $\begin{array}{l}\text { I use the words I learnt recently when speaking } \\
\text { with tourists and native speakers to pronounce } \\
\text { them correctly }\end{array}$ & 105 & 2.10 & .784 & .076 \\
\hline $\begin{array}{l}\text { I like to use English in fun ways. For example; I try } \\
\text { to make jokes in English }\end{array}$ & 105 & 2.30 & .798 & .078 \\
\hline $\begin{array}{l}\text { To improve my English I work with supporting } \\
\text { materials such as books, CDs that teach English }\end{array}$ & 105 & 2.23 & .800 & .078 \\
\hline I do tests to improve my English & 105 & 2.20 & .801 & .078 \\
\hline $\begin{array}{l}\text { While reading I try to guess the unknown structure } \\
\text { by comparing it with the one that I know }\end{array}$ & 105 & 2.30 & .733 & .072 \\
\hline $\begin{array}{l}\text { Before I write or listen in English I read about that } \\
\text { topic, revise the unit, read a similar paragraph, try } \\
\text { to find an example, prepare a draft or make } \\
\text { sentences with the topic }\end{array}$ & 105 & 2.14 & .739 & .072 \\
\hline $\begin{array}{l}\text { While speaking I think of words that might have a } \\
\text { similar meaning instead of the one that I do not } \\
\text { know }\end{array}$ & 105 & 2.43 & .732 & .071 \\
\hline Total & 105 & 18.07 & 3.36345 & \\
\hline
\end{tabular}

Table 6. Mean for Part C

\begin{tabular}{|c|c|c|c|c|}
\hline \multicolumn{5}{|l|}{ One-Sample Statistics } \\
\hline & $\mathrm{N}$ & Mean & $\begin{array}{l}\text { Std. } \\
\text { Deviation }\end{array}$ & $\begin{array}{l}\text { Std. } \\
\text { Error } \\
\text { Mean }\end{array}$ \\
\hline $\begin{array}{l}\text { I try to keep the words in my mind by associating their } \\
\text { pronunciation. For example, snake and sinek (a fly) }\end{array}$ & 105 & 2.22 & .796 & .078 \\
\hline $\begin{array}{l}\text { I take notes of unknown words, my friends' questions } \\
\text { or things that I remember after drama activities }\end{array}$ & 105 & 2.20 & .765 & .075 \\
\hline $\begin{array}{l}\text { I use gestures when I have trouble in explaining } \\
\text { meanings of things in English }\end{array}$ & 105 & 2.18 & .769 & .075 \\
\hline $\begin{array}{l}\text { While writing or speaking I draw the picture of an } \\
\text { unknown word }\end{array}$ & 105 & 1.85 & .818 & .080 \\
\hline $\begin{array}{l}\text { If I don't know the meaning of the word, I will say it in } \\
\text { my mother tongue and continue talking }\end{array}$ & 105 & 2.27 & .788 & .077 \\
\hline $\begin{array}{l}\text { I repeatedly write the new word to be able to say it } \\
\text { correctly }\end{array}$ & 105 & 2.02 & .734 & .072 \\
\hline $\begin{array}{l}\text { I benefit from words that has same meaning but in } \\
\text { different language to facilitate my writing and reading } \\
\text { comprehension while I read and write. For example, } \\
\text { radio, television, leopard, chimpanzee }\end{array}$ & 105 & 2.29 & .675 & .066 \\
\hline Total & 105 & 15.02 & 2.8588 & \\
\hline
\end{tabular}


Table 7. Mean for Part D

\begin{tabular}{|c|c|c|c|c|}
\hline \multicolumn{5}{|l|}{ One-Sample Statistics } \\
\hline & $\mathrm{N}$ & Mean & $\begin{array}{l}\text { Std. } \\
\text { Deviation }\end{array}$ & $\begin{array}{l}\text { Std. } \\
\text { Error } \\
\text { Mean }\end{array}$ \\
\hline $\begin{array}{l}\text { To facilitate my reading and listening } \\
\text { comprehension, writing and speaking I use } \\
\text { dictionaries, my course book, notebook or } \\
\text { language teaching CDs }\end{array}$ & 105 & 2.24 & .779 & .076 \\
\hline $\begin{array}{l}\text { I remember a word by thinking its location on a } \\
\text { page }\end{array}$ & 105 & 2.22 & .759 & .074 \\
\hline $\begin{array}{l}\text { I read or listen to an English text again after } \\
\text { reading or listening to it once }\end{array}$ & 105 & 2.26 & .785 & .077 \\
\hline $\begin{array}{l}\text { Before writing something I identify the words and } \\
\text { structures from my book and notebook }\end{array}$ & 105 & 2.29 & .717 & .070 \\
\hline I always do revision & 105 & 2.28 & .727 & .071 \\
\hline Total & 105 & 11.28 & 2.37574 & \\
\hline
\end{tabular}

\section{Conclusion}

Based on the findings of the study, it portrays that upper primary ESL learners have their own strategies of learning and are unlikely to practice the usage of learning strategies. Most of the young learners used to practice the learning strategies in their daily life but they are not aware of the strategies that they used can help them in improving their language learning especially in English. The finding reflects young learners prefer to use cognitive, metacognitive, social and compensation strategies to improve their language learning. In addition, the findings show that learners who answer the questionnaire are not aware of existence of LLS that they use in their language learning. Therefore, teachers need to take this opportunity to expose learners to various LLS that are applicable in their language learning to improve their selfvalue in achieving the standard of global demands. This also can help to enrich learners with multi-dimensional LLS in the second language acquisition.

LLS is proven to have a great impact on second language acquisition (e.g: Chamot, 1987; Hong-Nam \& Leavell, 2007; Alhaysony, 2017; Lawrence et al., 2017). However, most of the research on LLS predominantly focus on adults and adolescents compared to young learners. Hence, this study is significant because it focuses on ESL young learners' LLS by using CHILL which is an inventory specifically for young learners. It is hoped that this study is able to provide insight on strategies that can be used by young learners to acquire the target language effectively.

It is imperative to put into account that the good learning strategies for the learners are also depend on the teachers since they played an important role to build the learners' characters. Thus, the implication of this study shows that it is important for teachers in identifying appropriate and suitable LLS for young learners in acquiring the target language. The exposure of LLS by teachers enable the learners to identify the most suitable strategy that suit their language learning. Further research can aim to conduct to lower primary or preschool learners. This research will enlighten the stakeholders to be conscious of different types of LLS when designing the syllabus and curriculum. 


\section{References}

Akhyar, R., \& Fatimah, S. M. (2018). Characteristics of classroom interaction of English language teachers in Indonesia and Malaysia. International Journal of Language Education, 2(1), 40-50.

Alhaysony, M. (2017). Language learning strategies used by Saudi EFL students: The effect of duration of English language study and gender. Theory and Practice in Language Studies, $7(1), 18-28$.

Bhasin, H. (2020). The Importance of Language in Detail. http://www/nclrc.org/guides/HED/Marketing91/pdfs/full.pdf

Boset, S. A. A., Adelina, A., \& Nabeel, A. (2017). A conceptual analysis of the factors affecting EFL teachers' professional performance. International Journal of Language Education and Applied Linguistics (IJLEAL), 7.

Chamot, A. U. (1987). The Learning Strategies of ESL Students. In A. Wenden, \& J.Rubin, (eds) Learner Strategies in Language Learning. Englewood Cliffs, NJ: Prentice Hall. 71-83.

Creswell, J. W. (2012). Educational research: Planning, conducting, and evaluating quantitative and qualitative research. (4th ed.). Boston, MA: Pearson.

Gürsoy, E. (2013). Investigating language learning strategies of EFL Children for the development of a taxonomy. English Language Teaching, 3(3), 164-175.

Gürsoy, E., \& Eken, E. (2017). Identifying children's language learning strategies: Turkish example. Porta Linguarum: revista internacional de didáctica de las lenguas extranjeras, (30), 43-56.

Hong-Nam, K., \& Leavell, A. G. (2007). Language learning strategy use of ESL students in an intensive English learning context. System, 34(3), 399-415.

Ismail, N., \& Jabar, N. L. A. (2010). A Study on The Language Learning Strategies Used Among UHB 1412 Students. English For Academic Communication.

$\mathrm{Li}, \mathrm{H}$. (2019). Language learning strategies for digital classrooms. International Journal of English Literature and Social Sciences, 4(3), 635-640.

Khalid, A. K. (2017). The central characteristics of successful ESL/EFL teachers. Journal of Language Teaching and Research, 8(5), 881-890.

Khusnul, K. (2020). Improving students' writing skill through mind mapping strategy. IAIN Jember, 1 Jun: 4.

Kumar, R. (2011). Research Methodology: A step-by-step guide for beginners. 3th ed. Singapore: Sage Publication.

Lawrence, Z. J., Nathan, T., \& Tony, Q. L. (2019). Language learning strategy research in system: Looking back and looking forward. System, 84, 87-92

Lessard, M. (1997). Language Learning Strategies: An Overview for L2 Teachers. Essays in Languages and Literatures, 8 .

Nadzrah, B. A. (2007). English language activities in computer-based learning environment: A case study in ESL Malaysian classroom. GEMA Online Journal of Language Studies, 7(1).

Namaziandost, E., Imani, A., \& Ziafar, M. (2020). An investigation of Iranian EFL teachers and learners' attitudes towards using language learning strategies. Global Journal of Foreign Language Teaching, 10(1), 65-71.

Nguyen, H., \& Terry, D. R. (2017). English Learning Strategies among EFL Learners: A Narrative Approach. IAFOR Journal of Language Learning, 3(1), 4-19.

NoorAileen, I., Syafiq, M. S. Y., Thuraiya, M., Nur Ain, Z., Perumal, P. D., Azurawati, Z., \& Siti Maryam, A. Y. (2015). The importance of implementing collaborative learning in 
the English as a second language (ESL) classroom in Malaysia. Procedia Economics and Finance, 31, 346-353.

O'Malley, J. M., \& Chamot, A. (1990). Learning Strategies in Second Language Acquisition. Cambridge: Cambridge University Press.

Rukaia, I. R. (2017). Investigating factors that contribute to effective teaching-learning practices: EFL/ESL classroom context. English Language Teaching, 10(4), 15-21.

Šafranj, J., \& Gojkov-Rajić, A. (2018). The role of personality traits in the choice and use of language learning strategies. Društvena istraživanja: časopis za opća društvena pitanja, 28(4), 691-709.

Zeynali, S. (2012). Exploring the Gender Effect on EFL Learners' Learning Strategies. Theory \& Practice in Language Studies, 2(8). 